\section{The Contribution of the Brazilian Dental Journal to the Brazilian Scientific Research over 30 Years}

\author{
Carlos Estrela ${ }^{\circledR}{ }^{\circledR}$, Jesus Djalma Pécora ${ }^{2}{ }^{\circledR}$, Manoel Damião Sousa-Neto² ${ }^{\circledR}$
}

'Department of Stomatologic Sciences, School of Dentistry, UFG - Universidade Federal de Goiás, Goiânia, GO, Brazil

${ }^{2}$ Department of Restorative Dentistry, School of Dentistry of Ribeirão Preto, USP - Universidade de São Paulo, Ribeirão Preto, SP, Brazil

Correspondence : Prof. Dr. Carlos Estrela, Praça Universitária s/n, Setor Universitário, 74605-220 Goiânia, G0, Brazil. Tel: +55-62-3209-6254. e-mail:estrela3@terra.com.br
The Brazilian Dental Journal (BDJ) was officially launched in 1990, stimulated by the courage and boldness of researchers dedicated to teaching and research in dentistry. The journal was conceived in a worldwide coverage and universal language to allow publication of the results of Brazilian studies, which otherwise would not be accessible to the scientific dental community. In the year we celebrate the thirtieth anniversary of BDJ, this article presents a brief overview of Brazilian dental research and a bibliometric analysis of the articles published in this journal as a contribution to our readers and fellow researchers. The purpose was to identify the mot frequent categories of study, the most published areas of dentistry and BDJ's top 50 most-cited articles in the Scopus and Google Scholar databases. A search was performed on all BDJ online issues published from 1990 to 2019. In this period, BDJ published 1,710 articles. Based on their distribution by category of study, 557 articles were in the basic research/dental materials area, 527 in the basic research/biology area and 280 in the clinical research area. Eight articles were cited more than 100 times in the Scopus database and 266 times in the Google Scholar database. Endodontics was the most published area. This overview of BDJ production over those 30 years allows establishing a profile of the characteristics, impact and trends of the published studies, as well as the journal's contribution to the top 50 most-cited articles in the Scopus and Google Scholar databases.
Key Words: bibliometrics, Brazilian Dental Journal, metrics, publications.

\section{Introduction}

In 1990, the wish to spread the outcomes of high-quality Brazilian dental research in a universal language (English) inspired a group of professors (JDP, PCS, GMC and MDSN) to found the Brazilian Dental Journal (BDJ). In its essence, BDJ was conceived for Brazilian researchers, professors and clinicians to have the findings of theirs studies and clinical cases disclosed to the scientific community in Brazil and overseas.

The achievements were gradually emerging as the newborn journal consolidated, nonetheless permeated by countless temptations to give in to the struggle and challenges of self-maintenance. BDJ has become a bimonthly publication, with a diversified and experienced editorial board and a panel of peer-reviewers and contributors from different countries, institutions and areas of expertise.

While maintaining its original mission of spreading the Brazilian dental research to the world, BDJ has widen its scope years ago and also publishes articles from foreign authors. Currently, the journal is supported by National Council for Scientific and Technological Development $(\mathrm{CNPq})$, and the articles are indexed or summarized by PubMed-Medline, SCOPUS, Google-scholar, SciELO,
LILACS, Bibliografia Brasileira de Odontologia (BBO), Portal de Revistas da USP, Directory of Open Access Journals, DEDALUS and ERL.

In the year of celebration of BDJ's thirtieth anniversary, this article presents a brief overview of the Brazilian dental research and a bibliometric analysis of the article published in this journal as a contribution to our readers and fellow researchers. The purpose was to identify the most frequent category of study (systematic review, narrative review, clinical research, basic research / biology, basic research / technology, basic research / dental materials, case report and others); the most cited thematic areas (cariology, dental materials, endodontics, implantology, oral and maxillofacial surgery, oral radiology, oral pathology, restorative dentistry, pediatric dentistry, prosthetic dentistry, public health, periodontology, orthodontics, temporomandibular disorder and others) and BDJ's top 50 most-cited articles in the Scopus and Google Scholar databases

\section{Dental Research}

Every minute, the volume of information increases in geometric progression, imposing changes to the individuals and the incorporation of innovative and challenging behaviors. Human knowledge has been built since the 
creation of the world and mankind has witnessed countless changes. Thus, regardless of the area of expertise, research (knowledge) is responsible for feeding human evolution and constitutes immunity to ignorance. As far as health and clinical approaches are concerned, the search for real and primary problems is particularly crucial and all decisions must be made based on research of high scientific value (1).

The logic of research includes having clear objectives towards the improvement of life quality for the population, increase of country's economic power and the generation of jobs. Research is an instrument for science and technology - the first is the acquisition of real knowledge and the second provides the means for its acquisition, hence they cannot be set apart. It should be held in mind, although implicitly, that innovation is a reference, a goal. Teachers must build their clinical practice based on research, transmit and reinforce it to their students over the years, doing so within the correct assumption of the rational learning logic, in which both teachers and students feed on the learning process (1).

The advancement and worldwide respect for the Brazilian dental research has been outstanding in recent years. This is due to the efforts and investment of several institutions and faculty members, who have dedicated themselves and have struggled to provide infrastructure to research laboratories, train workers, researchers and graduate students and publish effective results in high impact journals, with a strong focus on excellence. High-quality dental research is only achieved by highly qualified researchers.

Challenges and difficulties (such as funding, priorities and criteria for resource allocation, structuring appropriate laboratories, training human resources in research, international collaborations with reference centers, encouraging publication in impact journals, among others) have never discouraged the idealists who set the goal of producing dental research at high level in Brazil.

In this sense, the concern with the quality of Brazilian dental research has been a real issue to those who live and experience the unveiling of problems and solutions. However, in order to achieve excellence, it is increasingly necessary to maintain strict methodological criteria and work within the parameters of competence.

In this perspective, to disclose a qualified study on the 30 years of $\mathrm{BDJ}$, a positive reflection includes all the contributions of this scientific communication resource, with national and international impact. This initiative of creating the BDJ also encouraged other Brazilian centers to publish other journals in English and having them indexed in important databases.

\section{BDJ Bibliometric Analysis}

The citations of an article represent good indicators of the study, the author(s) and even the journal. The references cited in an article are a source of information for other researchers and serve as criteria for selecting the subject, the journal, the study and the author one wishes to know more about.

Several studies (2-11) have reported the careful and judicious way these scientific recognition indexes, beyond information with specific characteristics, such as the advances achieved over the years. Based on the citations, one can assess the impact of a subject or a journal as well as the scientific production of a university or a country. In addition, these data may support trends, impact of themes and analyses of priorities. Important approaches to the most cited articles in different areas have already been investigated, signaling the scientific impacts, the advances in the different thematic areas, besides an inspiration to solve relevant problems (12-16).

Therefore, a manual search was performed by two evaluators on all articles published online by BDJ from 1990 to 2019. When results differed, a consensus was reached after the article was discussed with a third evaluator. Table 1 presents the 50 most-cited articles in Scopus and Google Scholar databases by the Brazilian Dental Journal. Figures 1 and 2 show the number of articles published in this period by area and category of study. From 1990 until 2019, BDJ published 1,710 scientific articles, distributed in the following areas (Fig. 1): endodontics (365 articles), restorative dentistry (317 articles), oral pathology (200 articles), periodontology (147 articles), prosthetic dentistry (140 articles), pediatric dentistry (95 articles), implantology (88 articles), oral and maxillofacial surgery (77 articles), cariology (75 articles), orthodontics (65 articles), dental materials (47 articles), oral radiology (32 articles), temporomandibular disorders (TMD) (25 articles), public health (18 articles) and others (19 articles).

The categories of study were distributed as follows (Fig. 2): basic research/dental materials (557 articles), basic research/biology (527 articles), clinical research (280 articles), case reports (192 articles), basic research/ technology (69 articles), narrative review (31 articles), systematic review (12 articles) and others (41 articles). Most of these categories are used by other journals and have been mentioned in previous studies $(17,18)$. When necessary, they were adjusted to respect the specificities of the BDJ. During the analysis of data, care was taken with studies from interconnected areas in order to avoid duplicity of data in the final counting of areas. Common sense prevailed in the analysis.

Endodontics was the most studied area with 365 published studies. Among categories of study, basic research/dental materials (557 articles) predominated. Eight articles were cited more than 100 times in the Scopus and more than 266 times in the Google Scholar databases. 
The citation indicators do not define the scientific merit of a researcher because citation is a complex process involving factors that extrapolate the researcher competence and laboratory quality and infrastructure (19). Nonetheless, citation indicators of (20-69) are important for a reflection on journal's editorial policy. The guidance, inspiration and critical analysis of future studies are often conceived from a reflection of the current knowledge.

\section{Final Considerations}

BDJ published 1,710 articles between its foundation in
1990 and 2019. Based on the distribution of the articles by categories of study, 557 articles were in the basic research/ dental materials area, 527 in basic research/biology and 280 in clinical research. Eight articles were cited more than 100 times in the Scopus database and more than 266 times in the Google Scholar database. Endodontics was the most published area. This overview of BDJ production over those 30 years allows establishing a profile of the characteristics, impact and trends of the published studies, as well as the journal's contribution to the top 50 most-cited articles in the Scopus and Google Scholar databases.

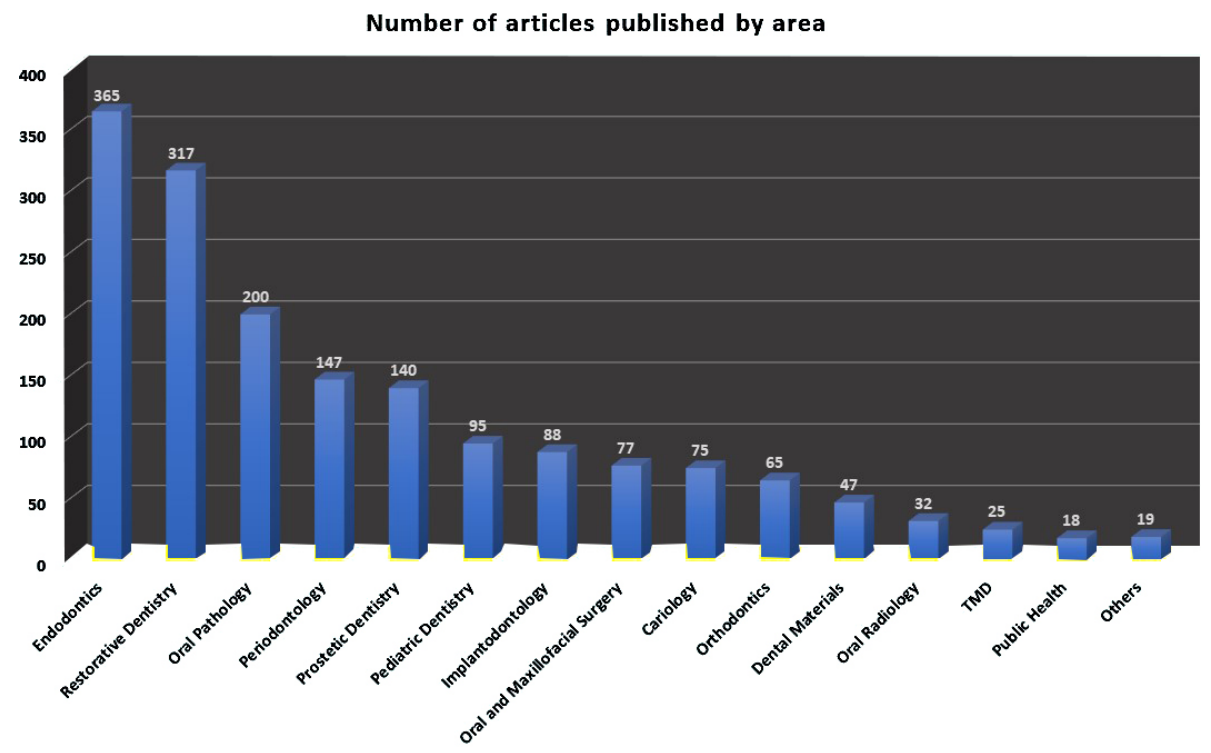

Figure 1. Distribution of articles published in BDJ (1990-2019) following thematic area.

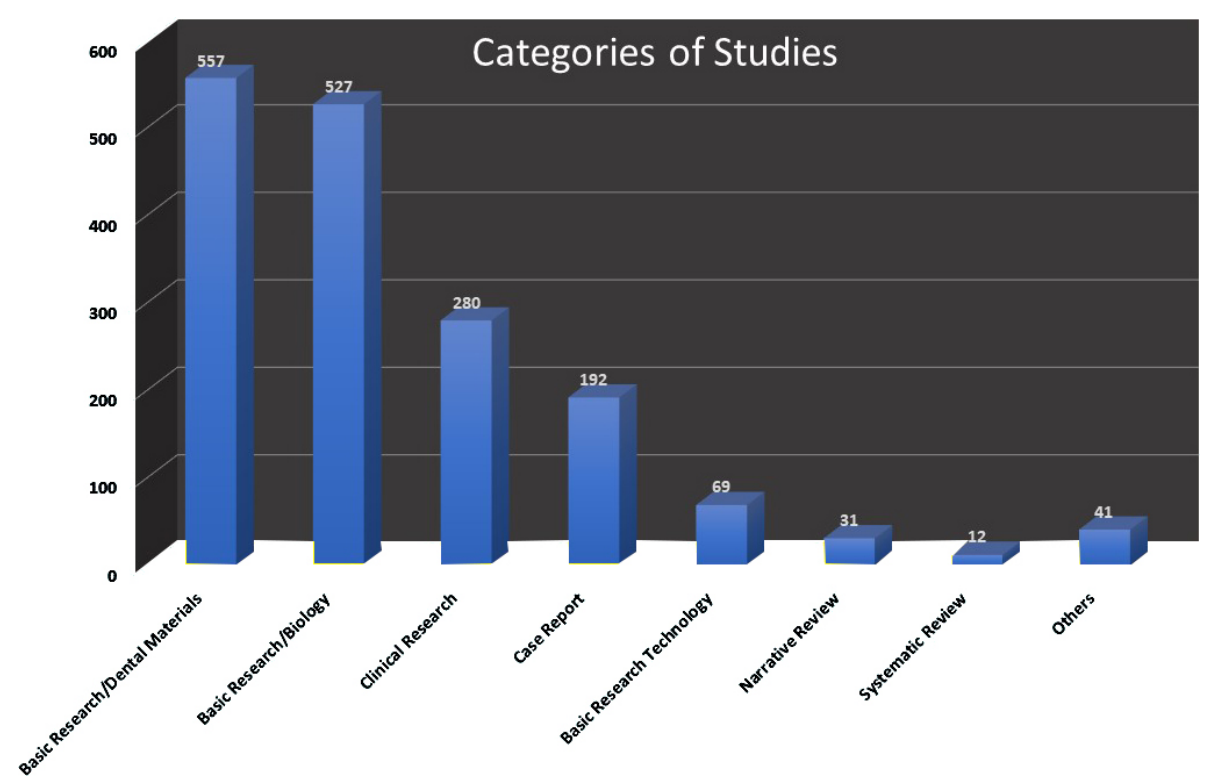

Figure 2. Distribution of articles published in BDJ (1990-2019) considering the categories of studies. 
Table 1. The top 50 most-cited papers in Brazilian Dental Journal

\begin{tabular}{|c|c|c|c|}
\hline Rank & Articles & $\begin{array}{l}\text { Scopus } \\
\text { (NC) }\end{array}$ & $\begin{array}{l}\text { Google } \\
\text { Scholar }\end{array}$ \\
\hline 1 & $\begin{array}{l}\text { Estrela C, Estrela CR, Barbin EL, Spanó JC, Marchesan MA, Pécora JD. Mechanism } \\
\text { of action of sodium hypochlorite. Braz Dent J 2002;13:113-117. }\end{array}$ & 237 & 670 \\
\hline 2 & $\begin{array}{l}\text { Estrela C, Bammann LL, Estrela CR, Silva RS, Pécora JD. Antimicrobial and chemical study of MTA, } \\
\text { Portland cement, calcium hydroxide paste, Sealapex and Dycal. Braz Dent J 2000;11:3-9. }\end{array}$ & 190 & 513 \\
\hline 3 & $\begin{array}{l}\text { Novaes Jr. AB, de Souza SLS, de Barros RRM, Pereira KKY, Iezzi G, Piattelli A. Influence } \\
\text { of implant surfaces on osseointegration. Braz Dent J 2010;21:471-481. }\end{array}$ & 139 & 253 \\
\hline 4 & $\begin{array}{l}\text { Estrela C, Sydney GB, Bammann LL, Felippe-Júnior O. Mechanism of action of calcium and } \\
\text { hydroxyl ions of calcium hydroxide on tissue and bacteria. Braz Dent J 1995;6:85-90. }\end{array}$ & 133 & 398 \\
\hline 5 & $\begin{array}{l}\text { Holland R, de Souza V, Murata SS, Nery MJ, Bernabé PF, Otoboni-Filho JA, Dezan- } \\
\text { Júnior E. Healing process of dog dental pulp after pulpotomy and pulp covering with } \\
\text { mineral trioxide aggregate or Portland cement. Braz Dent J 2001;12:109-113. }\end{array}$ & 133 & 322 \\
\hline 6 & $\begin{array}{l}\text { Aidar M, Line SRP. A simple and cost-effective protocol for DNA isolation } \\
\text { from buccal epithelial cells. Braz Dent J 2007;18:148-152. }\end{array}$ & 133 & 204 \\
\hline 7 & $\begin{array}{l}\text { López ME, Colloca ME, Páez RG, Schallmach JN, Koss MA, Chervonagura A. } \\
\text { Salivary characteristics of diabetic children. Braz Dent J 2003;14:26-31. }\end{array}$ & 108 & 240 \\
\hline 8 & $\begin{array}{l}\text { Holland R, Souza V, Nery MJ, Faraco-Júnior IM, Bernabé PF, Otoboni-Filho JA, Dezan- } \\
\text { Júnior E. Reaction of rat connective tissue to implanted dentin tube filled with mineral } \\
\text { trioxide aggregate, Portland cement or calcium hydroxide. Braz Dent J 2001;12:3-8. }\end{array}$ & 104 & 266 \\
\hline 9 & $\begin{array}{l}\text { Queiroz CS, Hara AT, Paes-Leme AF, Cury JA. pH-Cycling models to evaluate the effect of low } \\
\text { fluoride dentifrice on enamel De- and remineralization. Braz Dent J 2008;19;21-27. }\end{array}$ & 99 & 179 \\
\hline 10 & $\begin{array}{l}\text { Cury JA, Tenuta LMA, Ribeiro CCC, Paes-Leme AF. The importance of fluoride dentifrices } \\
\text { to the current dental caries prevalence in Brazil. Braz Dent J 2004;15:167-174. }\end{array}$ & 95 & 213 \\
\hline 11 & $\begin{array}{l}\text { Gajewski VES, Pfeifer CS, Fróes-Salgado NRG, Boaro LCC, Braga RR. Monomers used in resin composites: } \\
\text { Degree of conversion, mechanical properties and water sorption/solubility. Braz Dent J 2012;23:508-514. }\end{array}$ & 94 & 195 \\
\hline 12 & $\begin{array}{l}\text { Estrela C, Alencar AHG, Kitten GT, Vencio EF, Gava E. Mesenchymal stem cells in the } \\
\text { dental tissues: Perspectives for tissue regeneration. Braz Dent J 2011;22:91-98. }\end{array}$ & 92 & 193 \\
\hline 13 & $\begin{array}{l}\text { Rosa AL, Beloti MM. Effect of cpTi surface roughness on human bone marrow cell } \\
\text { attachment, proliferation, and differentiation. Braz Dent J 2003;14:16-21. }\end{array}$ & 90 & 141 \\
\hline 14 & $\begin{array}{l}\text { Shinohara EH, Martini MZ, Oliveira-Neto HG, Takahashi A. Oral myiasis } \\
\text { treated with ivermectin: Case report. Braz Dent J 2004;15:79-81. }\end{array}$ & 86 & 167 \\
\hline 15 & $\begin{array}{l}\text { Vasconcelos LCDS, Sampaio FC, Sampaio MCC, Pereira MDSV, Higino JS, Peixoto MHP. } \\
\text { Minimum inhibitory concentration of adherence of Punica granatum Linn (pomegranate) } \\
\text { gel against S. mutans, S. mitis and C. albicans. Braz Dent J 2006;17:223-227. }\end{array}$ & 84 & 206 \\
\hline 16 & $\begin{array}{l}\text { Ladalardo TCCGP, Pinheiro A, Campos RADC, Brugnera- Júnior, A, Zanin F, Albernaz PLM, Weckx } \\
\text { LLM. Laser therapy in the treatment of dentine hypersensitivity. Braz Dent J 2004;15:144-150. }\end{array}$ & 83 & 160 \\
\hline 17 & $\begin{array}{l}\text { Garcia EJ, Cadorin-Oldoni TL, Alencar SM, Reis A, Loguercio AD, Miranda-Grande RH. Antioxidant activity } \\
\text { by DPPH assay of potential solutions to be applied on bleached teeth. Braz Dent J 2012;23:22-27. }\end{array}$ & 81 & 210 \\
\hline 18 & $\begin{array}{l}\text { Gomes BPFA, Vianna ME, Zaia AA, Almeida JFA, Souza-Filho FJ, Ferraz CCR. } \\
\text { Chlorhexidine in endodontics. Braz Dent J 2013;24:89-102. }\end{array}$ & 78 & 168 \\
\hline 19 & $\begin{array}{l}\text { Zogheib LV, Della-Bona A, Kimpara ET, Mccabe JF. Effect of hydrofluoric acid etching duration on the } \\
\text { roughness and flexural strength of a lithium disilicate-based glass ceramic. Braz Dent J 2011;22:45-50. }\end{array}$ & 77 & 149 \\
\hline 20 & $\begin{array}{l}\text { Pécora JD, Woelfel JB, Sousa-Neto MD, Issa EP. Morphologic study of the } \\
\text { maxillary molars. Part II: Internal anatomy. Braz Dent J 1992;3:53-57. }\end{array}$ & 74 & 190 \\
\hline 21 & $\begin{array}{l}\text { Pinheiro AL, Limeira-Júnior FA, Gerbi ME, Ramalho LM, Marzola C, Ponzi EA. Effect of low level laser } \\
\text { therapy on the repair of bone defects grafted with inorganic bovine bone. Braz Dent J 2003;14:177-181. }\end{array}$ & 74 & 93 \\
\hline 22 & $\begin{array}{l}\text { Nunes VH, Silva RG, Alfredo E, Sousa-Neto MD, Silva-Sousa YTC. Adhesion of epiphany and AH } \\
\text { plus sealers to human root dentin treated with different solutions. Braz Dent J 2008;19:46-50. }\end{array}$ & 73 & 145 \\
\hline 23 & $\begin{array}{l}\text { Estrela C, Ribeiro RG, Estrela CR, Pécora JD, Sousa-Neto MD. Antimicrobial effect of 2\% sodium } \\
\text { hypochlorite and 2\% chlorhexidine tested by different methods. Braz Dent J 2003;14:58-62. }\end{array}$ & 72 & 244 \\
\hline 24 & Durack C, Patel S. Cone beam computed tomography in endodontics. Braz Dent J 2012;23:14:58-62. & 72 & 173 \\
\hline 25 & $\begin{array}{l}\text { Demarco FF, Conde MCM, Cavalcanti BN, Casagrande L, Sakai VT, Nör JE. } \\
\text { Dental pulp tissue engineering. Braz Dent J 2011;22:3-14. }\end{array}$ & 66 & 143 \\
\hline 26 & $\begin{array}{l}\text { Silva WJ, Seneviratne J, Parahitiyawa N, Rosa EAR, Samaranayake LP, del Bel Cury AA. Improvement of } \\
\text { XTT assay performance for studies involving Candida albicans biofilms.Braz Dent J 2008;19:364-369. }\end{array}$ & 65 & 110 \\
\hline
\end{tabular}


Pereira JV, Bergamo DCB, Pereira J0, França SDC, Pietro RCLR, Silva-Sousa YTC.

commonly found in endodontic infections. Braz Dent J 2005;16:192-196.

Oliveira MG, Xavier CB, Demarco FF, Pinheiro ALB, Costa AT, Pozza DH. Comparative chemical study of MTA and Portland cements. Braz Dent J 2007;18:3-7.

Spanó JC, Barbin EL, Santos TC, Guimarães LF, Pécora JD. Solvent action of sodium hypochlorite on bovine pulp and physico-chemical properties of resulting liquid. Braz Dent J 2001;12:154-157.

Holland R, Souza V, Nery MJ, Faraco-Júnior IM, Bernabé PF, Otoboni-Filho JA,

31 Dezan-Júnior E. Reaction of rat connective tissue to implanted dentin tubes filled with a white mineral trioxide aggregate. Braz Dent J 2002;13:23-26.

Estrela C, Bueno MR, Sousa-Neto MD, Pécora JD. Method for determination of root curvature radius using cone-beam computed tomography images. Braz Dent J 2008;19:114-118.

Estrela C, Holland R, Estrela CRA, Alencar AHG, Sousa-Neto MD, Pécora JD.

Characterization of successful root canal treatment. Braz Dent J 2014;25:3-11.

Mjör IA. Dentin permeability: The basis for understanding pulp reactions and adhesive technology. Braz Dent J 2009;20:3-16.

Giannini M, Makishi P, Ayres APA, Vermelho PM, Fronza BM, Nikaido T, Tagami J. SelfEtch adhesive systems: A literature review. Braz Dent J 2015;26:3-10.

Barbizam JVB, Trope M, Teixeira ECN, Tanomaru-Filho M, Teixeira FB. Effect of calcium hydroxide intracanal dressing on the bond strength of a resin-based endodontic sealer. Braz Dent J 2008;19:224-227.

Nunes E, Moraes IG, Novaes PM, Sousa SM. Bilateral fusion of mandibular second molars with supernumerary teeth: case report. Braz Dent J 2002;13:137-141.

Gomes BP, Ferraz CC, Vianna ME, Rosalen PL, Zaia AA, Teixeira FB, Souza-

Bernabé PFE, Holland R, Morandi R, Souza V, Nery NJ, Otobonni-Filho JÁ, Dezan-

Silva LAB, Nelson-Filho P, Faria G, Souza-Gugelmin MCM, Ito IY. Bacterial profile in primary teeth with necrotic pulp and periapical lesions. Braz dent J 2006;17:144-148.

Zogheib LV, Pereira JR, Valle AL, Oliveira JA, Pegoraro LF. Fracture resistance of weakened roots restored with composite resin and glass fiber post. Braz Dent J 2008;19:329-333.

Beloti MM, Rosa AL. Osteoblast differentiation of human bone marrow cells under continuous and discontinuous treatment with dexamethasone. Braz Dent J 2005;16:156-161.

Dostalova T, Jelinkova H, Housova D, Sulc J, Nemec M, Miyagi M, Brugnera-Júnior A, Zanin F. Diode laser-activated bleaching. Braz Dent J 2004;15:S13-8.

Ferraz CCR, Gomes BPFA, Zaia AA, Teixeira FB, Souza-Filho FJ. Comparative study

44 of the antimicrobial efficacy of chlorhexidine gel, chlorhexidine solution and sodium hypochlorite as endodontic irrigants. Braz Dent J 2007;18:294-298.

Correr AB, Sinhoreti MAC, Sobrinho LC, Tango RN, Schneider LFJ, Consani S. Effect of

45 the increase of energy density on knoop hardness of dental composites light-cured by conventional QTH, LED and xenon plasma arc. Braz Dent J 2005;16:218-224.

Tramontina VA, Machado MA, Nogueira-Filho GR, Kim SH, Vizzioli MR, Toledo

46 S. Effect of bismuth subgallate (local hemostatic agent) on wound healing in rats. Histological and histometric findings. Braz Dent J 2002;13:11-16.

Quirino MR, Birman EG, Paula CR. Oral manifestations of diabetes mellitus in controlled and uncontrolled patients. Braz Dent J 1995;6:11-136.

Nomura K, Vitti M, Oliveira AS, Chaves TC, Semprini M, Siéssere S, Hallak JE, Regalo SC. Use disorders in Brazilian dental undergraduates. Braz Dent J 2007;18:163-167. 


\section{Resumo}

A coragem e ousadia de pesquisadores dedicados ao ensino e pesquisa em odontologia incentivaram a criação em 1990 do Brazilian Dental Journal (BDJ). Esta revista nasceu com o objetivo de permitir a divulgação de resultados de pesquisas brasileiras em uma abrangência e linguagem universal para o mundo. Certamente, estes dados poderiam não ser de conhecimento público para a comunidade científica da odontologia. No ano de comemoração do trigésimo aniversário do BDJ, este estudo apresenta uma breve reflexão envolvendo a pesquisa odontológica e uma análise bibliométrica das publicações desta revista, que podem contribuir para profissionais, pesquisadores e colegas estrangeiros da odontologia. Nesse contexto, buscou-se identificar os 50 artigos mais citados nas bases de dados Scopus e Google Scholar, as áreas mais citadas e as categorias de estudos. Portanto, foi realizada uma pesquisa manual em todos os números do BDJ publicados on-line de 1990 a 2019. 0 BDJ publicou 1710 artigos científicos, sendo 557 artigos na área de pesquisa básica/ materiais dentários, 527 artigos na área de pesquisa básica/biologia e 280 artigos em pesquisa clínica. Oito artigos foram citados mais de 100 vezes no Scopus e 266 na base de dados do Google Scholar. A endodontia foi a área temática mais estudada. 0 panorama geral das publicações feitas no BDJ em comemoração ao seu trigésimo ano de existência permite uma análise das caracteristicas, impacto e tendências dos estudos, bem como a contribuição dos os 50 trabalhos mais citados nas bases de dados Scopus e Google Scholar.

\section{Acknowledgements}

The authors deny any conflicts of interest related to this study. BDJ thank and acknowledge Text \& Technical editors Sara Marchesan and Renata ๘

Pereira Ramos for the indispensable editorial and language review work.

\section{References}

1. Estrela C, Del Bel Cury AA. Research and dentistry. In: Estrela C. Scientific methodology: Science, teaching, research. 3rd ed. Artmed: Porto Alegre, RS, Brazil, 2018. p.3-6.

2. Adams $A B$, Simonson D. Publication, citations, and impact factors of leading investigators in critical care medicine. Respir Care 2004:49:276-281.

3. Adams J, Gurney K, Marshall S. Profiling citation impact: A new methodology. Scientometrics 2007;72:325-344

4. Hirsch JE. An index to quantify an individual's scientific research output. Proc Natl Acad Sci USA 2005;102:16569-72.

5. Cheek J, Garnham B, Quan J. What's in a number? issues in providing evidence of impact and quality of research(ers). Qual Health Res 2006;16:423-35.

6. Moed H. Citation analysis in research evaluation. Dordrecht: Springer; 2005. p.285-290.

7. Moed H. New developments in the use of citation analysis in research evaluation. Arch Immunol Ther Exp 2009;57:13-8.

8. Parker JN, Allesina S, Lortie CJ. Characterizing a scientific elite (B): publication and citation patterns of the most highly cited scientists in environmental science and ecology. Scientometrics 2013;94:469-480.

9. Ioannidis J, Boyack KW, Small H, Sorensen AA, Klavans R. Bibliometrics: is your most cited work your best? Nature 2014;514:561-562.

10. Hemmat Esfe M, Wongwises S, Asadi A, Karimipour A, Akbari M. Mandatory and self-citation; types, reasons, their benefits and disadvantages. Sci Eng Ethics 2015;21:1581-1585.

11. Ioannidis J. A generalized view of self-citation: direct, co-author, collaborative, and coercive induced self-citation. J Psychosom Res 2015;78:7-11.

12. Garfield E. 100 citation classics from the Journal of the American Medical Association. J Amer Med Ass 1987;257:52-59.

13. Ahmad P, Alam MK, Jakubovics NS, Schwendicke F, Asif JA. 100 years of the Journal of Dental Research: A bibliometric analysis. J Dent Res 2019;98:1425-1436.

14. Perazzo MF, Otoni ALC, Costa MS, Granville-Granville AF, Paiva SM,
Martins-Júnior PA. The top 100 most-cited papers in paediatric dentistry journals: A bibliometric analysis. Int J Paediatr Dent 2019;29:692-711.

15. Gonçalves APG, Plá AL, Rodolfo B, Nahsan FP, Correa MB, Moraes RR. Top-100 most-cited dental articles with authors from Brazil. Braz Dent J 2019;30:96-105.

16. Ordinola-Zapata R, Peters OA, Nagendrababu V, Azevedo B, Dummer PMH, Neelakantan P. What is of interest in Endodontology? A bibliometric review of research published in the International Endodontic Journal and the Journal of Endodontics from 1980 to 2019. Int Endod J 2020:53:36-52.

17. Freire MC, Pattussi MP. Tipos de estudo. In: Estrela C. Scientific methodology: Science, teaching, research. 3rd ed. Artmed: Porto Alegre, RS, Brazil, 2018. p.117-136.

18. Röhrig B, du Prel J-B, Wachtlin D, Blettner M. Types of study in medical research. Part 3. Series on evaluation of scientific publications. Dtsch Arztebl Int 2009:106:262-268.

19. Estrela C, Del Bel Cury AA. Evaluation of scientific merit. Braz Oral Res 2013;27:297-298.

20. Estrela $C$, Estrela CR, Barbin EL, Spanó JC, Marchesan MA, Pécora JD. Mechanism of action of sodium hypochlorite. Braz Dent J 2002;13:113117.

21. Estrela C, Bammann LL, Estrela CR, Silva RS, Pécora JD. Antimicrobial and chemical study of MTA, Portland cement, calcium hydroxide paste, Sealapex and Dycal. Braz Dent J 2000;11:3-9.

22. Novaes Jr. AB, de Souza SLS, de Barros RRM, Pereira KKY, lezzi $G$, Piattelli A. Influence of implant surfaces on osseointegration. Braz Dent J 2010;21:471-481.

23. Estrela C, Sydney GB, Bammann LL, Felippe-Júnior O. Mechanism of action of calcium and hydroxyl ions of calcium hydroxide on tissue and bacteria. Braz Dent J 1995;6:85-90.

24. Holland R, de Souza V, Murata SS, Nery MJ, Bernabé PF, Otoboni-Filho $J A$, Dezan-Júnior E. Healing process of dog dental pulp after pulpotomy and pulp covering with mineral trioxide aggregate or Portland cement. Braz Dent J 2001;12:109-113.

25. Aidar M, Line SRP. A simple and cost-effective protocol for DNA isolation from buccal epithelial cells. Braz Dent J 2007;18:148-152.

26. López ME, Colloca ME, Páez RG, Schallmach JN, Koss MA, Chervonagura A. Salivary characteristics of diabetic children. Braz Dent J 2003;14:2631.

27. Holland R, Souza V, Nery MJ, Faraco-Júnior IM, Bernabé PF, OtoboniFilho JA, Dezan-Júnior E. Reaction of rat connective tissue to implanted dentin tube filled with mineral trioxide aggregate, Portland cement or calcium hydroxide. Braz Dent J 2001;12:3-8.

28. Queiroz CS, Hara AT, Paes-Leme AF, Cury JA. pH-Cycling models to evaluate the effect of low fluoride dentifrice on enamel De- and remineralization. Braz Dent J 2008;19;21-27.

29. Cury JA, Tenuta LMA, Ribeiro CCC, Paes-Leme AF. The importance of fluoride dentifrices to the current dental caries prevalence in Brazil. Braz Dent J 2004;15:167-174.

30. Gajewski VES, Pfeifer CS, Fróes-Salgado NRG, Boaro LCC, Braga RR. Monomers used in resin composites: Degree of conversion, mechanical properties and water sorption/solubility. Braz Dent J 2012;23:508-514.

31. Estrela C, Alencar AHG, Kitten GT, Vencio EF, Gava E. Mesenchymal stem cells in the dental tissues: Perspectives for tissue regeneration. Braz Dent J 2011;22:91-98.

32. Rosa AL, Beloti MM. Effect of cpTi surface roughness on human bone marrow cell attachment, proliferation, and differentiation. Braz Dent J 2003;14:16-21.

33. Shinohara $\mathrm{EH}$, Martini $\mathrm{MZ}$, Oliveira-Neto HG, Takahashi A. Oral myiasis treated with ivermectin: Case report. Braz Dent J 2004;15:79-81.

34. Vasconcelos LCDS, Sampaio FC, Sampaio MCC, Pereira MDSV, Higino JS, Peixoto MHP. Minimum inhibitory concentration of adherence of Punica granatum Linn (pomegranate) gel against S. mutans, S. mitis and C. albicans. Braz Dent J 2006;17:223-227.

35. Ladalardo TCCGP, Pinheiro A, Campos RADC, Brugnera- Júnior, A, Zanin F, Albernaz PLM, Weckx LLM. Laser therapy in the treatment of dentine hypersensitivity. Braz Dent J 2004;15:144-150.

36. Garcia EJ, Cadorin-Oldoni TL, Alencar SM, Reis $A$, Loguercio AD, 
Miranda-Grande RH. Antioxidant activity by DPPH assay of potential solutions to be applied on bleached teeth. Braz Dent J 2012;23:22-27.

37. Gomes BPFA, Vianna ME, Zaia AA, Almeida JFA, Souza-Filho FJ, Ferraz CCR. Chlorhexidine in endodontics. Braz Dent J 2013;24:89-102.

38. Zogheib LV, Della-Bona A, Kimpara ET, Mccabe JF. Effect of hydrofluoric acid etching duration on the roughness and flexural strength of a lithium disilicate-based glass ceramic. Braz Dent J 2011;22:45-50.

39. Pécora JD, Woelfel JB, Sousa-Neto MD, Issa EP. Morphologic study of the maxillary molars. Part II: Internal anatomy. Braz Dent J 1992;3:5357.

40. Pinheiro AL, Limeira-Júnior FA, Gerbi ME, Ramalho LM, Marzola $C$, Ponzi EA. Effect of low level laser therapy on the repair of bone defects grafted with inorganic bovine bone. Braz Dent J 2003;14:177-181.

41. Nunes VH, Silva RG, Alfredo E, Sousa-Neto MD, Silva-Sousa YTC. Adhesion of epiphany and AH plus sealers to human root dentin treated with different solutions. Braz Dent J 2008;19:46-50.

42. Estrela C, Ribeiro RG, Estrela CR, Pécora JD, Sousa-Neto MD. Antimicrobial effect of 2\% sodium hypochlorite and $2 \%$ chlorhexidine tested by different methods. Braz Dent J 2003;14:58-62.

43. Durack $C$, Patel $\mathrm{S}$. Cone beam computed tomography in endodontics. Braz Dent J 2012;23:14:58-62.

44. Demarco FF, Conde MCM, Cavalcanti BN, Casagrande L, Sakai VT, Nör JE. Dental pulp tissue engineering. Braz Dent J 2011;22:3-14.

45. Silva WJ, Seneviratne J, Parahitiyawa N, Rosa EAR, Samaranayake LP, del Bel Cury AA. Improvement of XTT assay performance for studies involving Candida albicans biofilms.Braz Dent J 2008;19:364-369.

46. Siqueira-Júnior JF, Rôças IN. Bacterial pathogenesis and mediators in apical periodontitis. Braz Dent J 2007;18:267-280.

47. Pereira JV, Bergamo DCB, Pereira JO, França SDC, Pietro RCLR, SilvaSousa YTC. Antimicrobial activity of Arctium lappa constituents against microorganisms commonly found in endodontic infections. Braz Dent J 2005;16:192-196.

48. Oliveira MG, Xavier CB, Demarco FF, Pinheiro ALB, Costa AT, Pozza DH. Comparative chemical study of MTA and Portland cements. Braz Dent J 2007;18:3-7.

49. Spanó JC, Barbin EL, Santos TC, Guimarães LF, Pécora JD. Solvent action of sodium hypochlorite on bovine pulp and physico-chemical properties of resulting liquid. Braz Dent J 2001;12:154-157.

50. Holland R, Souza V, Nery MJ, Faraco-Júnior IM, Bernabé PF, OtoboniFilho JA, Dezan-Júnior E. Reaction of rat connective tissue to implanted dentin tubes filled with a white mineral trioxide aggregate. Braz Dent J 2002;13:23-26.

51. Estrela C, Bueno MR, Sousa-Neto MD, Pécora JD. Method for determination of root curvature radius using cone-beam computed tomography images. Braz Dent J 2008;19:114-118.

52. Estrela $C$, Holland R, Estrela CRA, Alencar AHG, Sousa-Neto MD, Pécora JD. Characterization of successful root canal treatment. Braz Dent J 2014;25:3-11.

53. Mjör IA. Dentin permeability: The basis for understanding pulp reactions and adhesive technology. Braz Dent J 2009;20:3-16.

54. Giannini M, Makishi P, Ayres APA, Vermelho PM, Fronza BM, Nikaido T, Tagami J. Self-Etch adhesive systems: A literature review. Braz Dent J 2015;26:3-10.

55. Barbizam JVB, Trope M, Teixeira ECN, Tanomaru-Filho M, Teixeira FB. Effect of calcium hydroxide intracanal dressing on the bond strength of a resin-based endodontic sealer. Braz Dent J 2008;19:224-227.

56. Nunes E, Moraes IG, Novaes PM, Sousa SM. Bilateral fusion of mandibular second molars with supernumerary teeth: case report. Braz Dent J 2002;13:137-141.

57. Gomes BP, Ferraz CC, Vianna ME, Rosalen PL, Zaia AA, Teixeira FB, Souza-Filho FJ. In vitro antimicrobial activity of calcium hydroxide pastes and their vehicles against selected microorganisms. Braz Dent $J$ 2002;13:155-161.

58. Bernabé PFE, Holland R, Morandi R, Souza V, Nery NJ, Otobonni-Filho $J A ́$, Dezan-Júnior E, Gomes-Filho JE. Comparative study of MTA and other materials in retrofilling of pulpless dog's teeth. Braz Dent $J$ 2005; 16:149-155.

59. Silva $L A B$, Nelson-Filho P, Faria G, Souza-Gugelmin MCM, Ito IY. Bacterial profile in primary teeth with necrotic pulp and periapical lesions. Braz dent J 2006;17:144-148.

60. Zogheib LV, Pereira JR, Valle AL, Oliveira JA, Pegoraro LF. Fracture resistance of weakened roots restored with composite resin and glass fiber post. Braz Dent J 2008;19:329-333.

61. Beloti MM, Rosa AL. Osteoblast differentiation of human bone marrow cells under continuous and discontinuous treatment with dexamethasone. Braz Dent J 2005;16:156-161.

62. Dostalova $T$, Jelinkova $H$, Housova $D$, Sulc J, Nemec M, Miyagi $M$, Brugnera-Júnior A, Zanin F. Diode laser-activated bleaching. Braz Dent J 2004;15:S13-8.

63. Ferraz CCR, Gomes BPFA, Zaia AA, Teixeira FB, Souza-Filho FJ. Comparative study of the antimicrobial efficacy of chlorhexidine gel, chlorhexidine solution and sodium hypochlorite as endodontic irrigants. Braz Dent J 2007;18:294-298.

64. Correr $A B$, Sinhoreti MAC, Sobrinho LC, Tango RN, Schneider LFJ, Consani S. Effect of the increase of energy density on knoop hardness of dental composites light-cured by conventional QTH, LED and xenon plasma arc. Braz Dent J 2005;16:218-224.

65. Tramontina VA, Machado MA, Nogueira-Filho GR, Kim SH, Vizzioli MR, Toledo S. Effect of bismuth subgallate (local hemostatic agent) on wound healing in rats. Histological and histometric findings. Braz Dent J 2002;13:11-16.

66. Quirino MR, Birman EG, Paula CR. Oral manifestations of diabetes mellitus in controlled and uncontrolled patients. Braz Dent 1995;6:11-136.

67. Nomura $K$, Vitti $M$, Oliveira AS, Chaves TC, Semprini $M$, Siéssere $S$, Hallak JE, Regalo SC. Use of the Fonseca's questionnaire to assess the prevalence and severity of temporomandibular disorders in Brazilian dental undergraduates. Braz Dent J 2007;18:163-167.

68. Rocha SS, Adabo GL, Henriques GEP, Nóbilo MADA. Vickers hardness of cast commercially pure titanium and Ti-6Al-4V alloy submitted to heat treatments. Braz Dent J 2006;17:126-129.

69. Soares CJ, Valdivia ADCM, Silva GR, Santana FR, Menezes MS. Longitudinal clinical evaluation of post systems: A literature review. Braz Dent J 2012;23:135-140. 